\title{
The Prion-Like Properties of Amyloid- $\beta$ Assemblies: Implications for Alzheimer's Disease
}

\author{
Lary C. Walker, ${ }^{1}$ Juliane Schelle, ${ }^{2,3}$ and Mathias Jucker ${ }^{2,3}$ \\ ${ }^{1}$ Yerkes National Primate Research Center and Department of Neurology, Emory University, \\ Atlanta, Georgia 30322 \\ ${ }^{2}$ Department of Cellular Neurology, Hertie Institute for Clinical Brain Research, \\ University of Tübingen, D-72076 Tübingen, Germany \\ ${ }^{3}$ German Center for Neurodegenerative Diseases (DZNE), D-72076 Tübingen, Germany \\ Correspondence: mathias.jucker@uni-tuebingen.de; lary.walker@emory.edu
}

Since the discovery that prion diseases can be transmitted to experimental animals by inoculation with afflicted brain matter, researchers have speculated that the brains of patients suffering from other neurodegenerative diseases might also harbor causative agents with transmissible properties. Foremost among these disorders is Alzheimer's disease (AD), the most common cause of dementia in the elderly. A growing body of research supports the concept that the pathogenesis of $A D$ is initiated and sustained by the endogenous, seeded misfolding and aggregation of the protein fragment amyloid- $\beta(A \beta)$. At the molecular level, this mechanism of nucleated protein self-assembly is virtually identical to that of prions consisting of the prion protein $(\mathrm{PrP})$. The formation, propagation, and spread of $A \beta$ seeds within the brain can thus be considered a fundamental feature of $\mathrm{AD}$ pathogenesis.

\begin{abstract}
A zheimer's disease (AD) is the most frequent cause of dementia and a growing social, medical, and economic challenge to societies in which the elderly population is rapidly growing (Dartigues 2009; Holtzman et al. 2011; Reitz et al. 2011). The involvement of abnormal proteins in $\mathrm{AD}$ has been evident since Alois Alzheimer's original histopathological descriptions of the disease in the early 20th century (Alzheimer 1906). Even today, a conclusive diagnosis of $\mathrm{AD}$ in a patient with dementia requires the significant presence of two cardinal brain lesions at autopsy: amyloid- $\beta(A \beta)$ plaques and neurofibrillary tangles (NFTs) (Fig. 1). The de-
\end{abstract}

fining components of plaques are extracellular collections of aggregated $A \beta$ protein, whereas NFTs consist of intracellular bundles of hyperphosphorylated tau protein (Duyckaerts et al. 2009; Holtzman et al. 2011). In both cases, the proteins that accumulate assume a tertiary structure (or fold) that is unusually rich in $\beta$ sheet, which in turn promotes the structural corruption and self-assembly of like molecules into small oligomeric and larger fibrillar assemblies with neurotoxic properties (Haass and Selkoe 2007; Klein 2013). The resulting aggregates have features that are often characteristic of amyloid (Eisenberg and Jucker 2012). Although

Editor: Stanley B. Prusiner

Additional Perspectives on Prion Diseases available at www.perspectivesinmedicine.org

Copyright (C) 2016 Cold Spring Harbor Laboratory Press; all rights reserved

Advanced Online Article. Cite this article as Cold Spring Harb Perspect Med doi: 10.1101/cshperspect.a024398 
L.C. Walker et al.

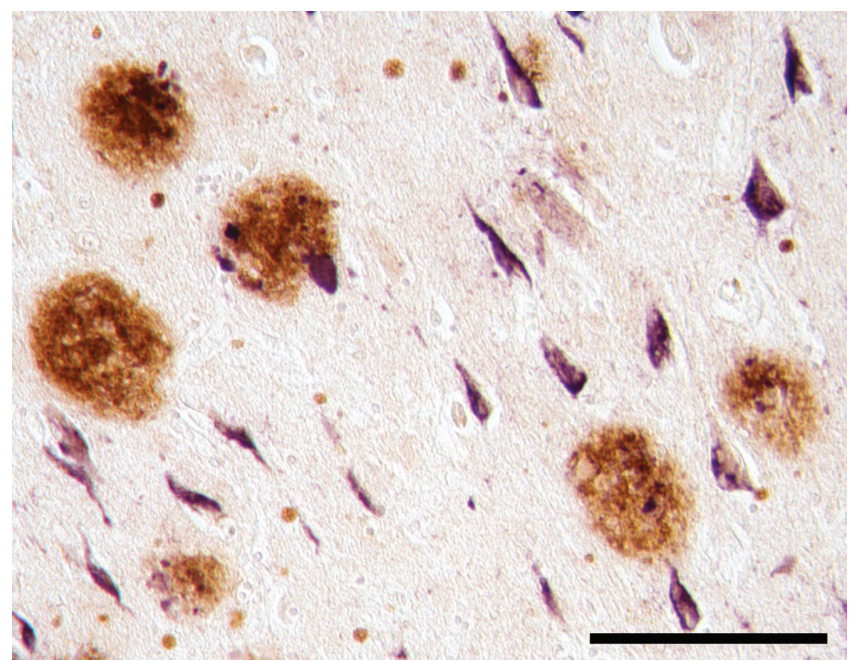

Figure 1. The canonical histopathology of Alzheimer's disease (AD). Amyloid- $\beta$ (A $\beta$ ) plaques consist of extracellular deposits of $A \beta$ (brown; detected by immunostaining with a polyclonal antibody to $A \beta$ ), and neurofibrillary tangles (NFTs) consist of intracellular masses of ectopic tau protein (purple; detected by immunostaining with a monoclonal antibody to tau). Scale bar, $100 \mu \mathrm{m}$.

the presence of amyloid signifies a proteopathic process, amyloid per se is not always required for the complete manifestation of disease. Both $\mathrm{A} \beta$ plaques (Fig. 2) and tau lesions can be modeled in transgenic mice (Jucker 2010). With the progression of $\mathrm{AD}, \mathrm{A} \beta$ deposition and NFTs increase in number and affect large areas of the brain in a characteristic and brain region- specific manner (Braak and Braak 1991; Thal et al. 2002; Jucker and Walker 2013). In addition to these pathological hallmarks and diagnostic lesions, the $\mathrm{AD}$ brain is typified by impaired synaptic function, neuroinflammation, and neuronal loss, which ultimately contribute to the full expression of dementia (Holtzman et al. 2011; Nelson et al. 2012).

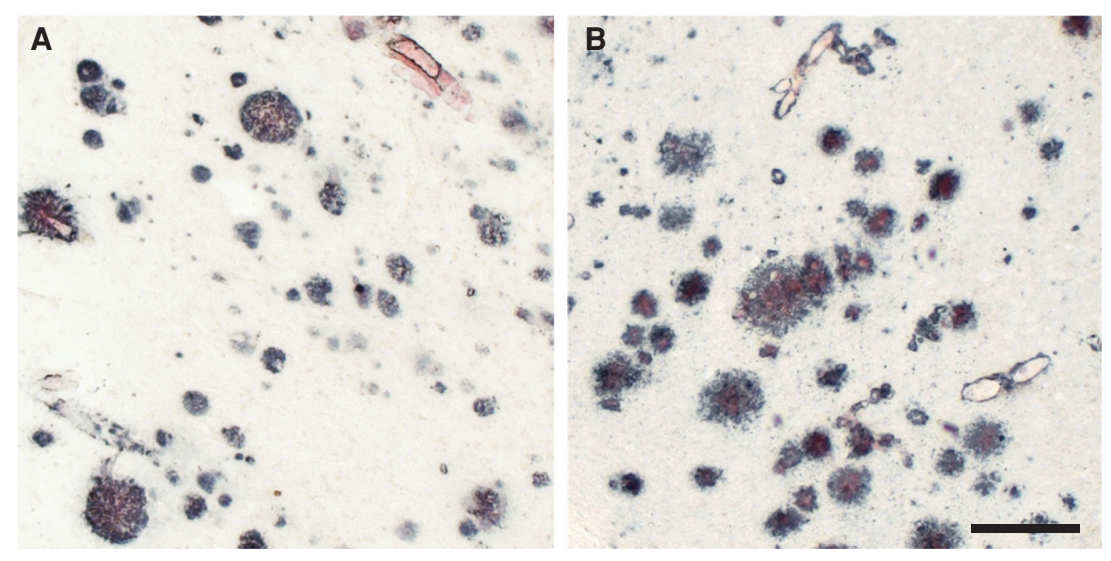

Figure 2. Similar appearance of amyloid- $\beta(\mathrm{A} \beta)$ deposits in the brain of an Alzheimer's disease (AD) patient and an $\mathrm{A} \beta$-precursor protein (APP)-transgenic mouse model. $(A) \mathrm{A} \beta$ deposits in the neocortex of an $\mathrm{AD}$ patient. (B) A $\beta$ deposits in the neocortex of an APP23 transgenic mouse. An anti-A $\beta$ specific polyclonal antibody (black) was used for immunostaining. Sections were counterstained with Congo red, a generic stain for amyloid. Scale bar, $200 \mu \mathrm{m}$. 
Prion-Like Properties of Aggregated A $\beta$

In addition to plaques, $A \beta$ accumulates to a variable extent in the walls of cerebral blood vessels in $\mathrm{AD}$ patients; this cerebral amyloid angiopathy (CAA) of the A $\beta$-type, although not pathognomonic for $\mathrm{AD}$, is a risk factor for hemorrhagic stroke (Yamada 2013) and can independently contribute to cognitive decline (Biffi and Greenberg 2011; Reijmer et al. 2015). Moreover, in most cases of AD ( particularly in older patients), typical pathological features are accompanied by variable amounts of comorbid lesions, such as vascular abnormalities and/or aggregates of other, non-AD-specific pathogenic proteins such as $\alpha$-synuclein, TDP-43, and others (Neuropathology Group, Medical Research Council Cognitive Function and Aging Study 2001; Knopman et al. 2003; Schneider et al. 2007; Nelson et al. 2012).

\section{THE PRIMACY OF A $\beta$ IN THE AD PATHOGENIC CASCADE}

Although the degree of tauopathy correlates more strongly with cognitive decline than does the buildup of $A \beta$ (Giannakopoulos et al. 2003), extant evidence indicates that in $\mathrm{AD}$ (Hardy and Selkoe 2002; Holtzman et al. 2011; Nelson et al. 2012) and in genetically modified mice (Götz et al. 2001; Lewis et al. 2001; Bolmont et al. 2007; Héraud et al. 2014; Stancu et al. 2014; Vasconcelos et al. 2016), tauopathy is downstream from $A \beta$ proteopathy. Moreover, the genetic causes of autosomal dominant AD identified so far all affect $A \beta$ by enhancing its release from the $A \beta$-precursor protein (APP) or its tendency to self-aggregate (Hardy and Selkoe 2002). In contrast, a rare mutation in the APP gene that causes an amino acid substitution at position 2 of $A \beta$ (A673Taccording to APP770 numbering) reduces the production of $A \beta$ following $\beta$ secretase cleavage (Jonsson et al. 2012) and also lowers the propensity of $A \beta$ to aggregate (Benilova et al. 2014); the A673T mutation thereby also lessens the risk of developing AD (Jonsson et al. 2012). Substitution of valine for alanine at this site $(\mathrm{A} 673 \mathrm{~V})$ enhances the production and aggregation of $A \beta$ and causes an autosomal recessive form of AD (Di Fede et al. 2009). Furthermore, assessment of biomarkers in subjects with autosomal dominant causative mutations and in subjects with idiopathic AD before the likely age of dementia onset shows that $A \beta$ changes in the brain are the first harbinger of impending disease, and that this can occur decades before clinical dementia sets in (Jack et al. 2010; Holtzman et al. 2011; Selkoe 2011; Bateman et al. 2012). These findings together highlight the pivotal role of $A \beta$ in the pathogenesis of AD.

\section{EXPERIMENTAL EVIDENCE FOR THE PRION- LIKE SEEDING OF A $\beta$ AGGREGATION}

Since the discovery that prion diseases can be transmitted to experimental animals by inoculation with afflicted brain fractions, researchers have speculated that the brains of patients suffering from other neurodegenerative diseases might also harbor causative agents with transmissible properties (Prusiner 1984; Gajdusek 1994). A team in Great Britain reported that $\mathrm{A} \beta$ load is increased in the brains of nonhuman primates by the intracerebral injection of $\mathrm{AD}$ brain homogenates (Baker et al. 1993). However, the experiments required an incubation period of $>5 \mathrm{yr}$, and the causative agent and mechanism of action remained uncertain. In the late 1990s, as the first transgenic mouse models of cerebral $\beta$-amyloidosis became available (Games et al. 1995; Hsiao et al. 1996; Sturchler-Pierrat et al. 1997), we set out to definitively test the hypothesis that the prion paradigm of nucleated protein self-assembly also applies to A $\beta$. This series of studies, in conjunction with investigations in other laboratories, now provides support for the concept that the molecular properties of pathogenic $A \beta$ assemblies are virtually identical to those of prion protein (PrP) prions (Walker and Jucker 2015).

In our first experiments, extracts of autopsyderived brain samples from $\mathrm{AD}$ patients and controls were injected stereotaxically into the hippocampal formation and/or neocortex of young, predepositing APP-transgenic mice (Kane et al. 2000; Walker et al. 2002; MeyerLuehmann et al. 2006). After incubation periods ranging from a few hours to $12 \mathrm{mo}$, the brains were analyzed immunohistochemically. Because only small amounts of extract were injected 


\section{L.C. Walker et al.}

(typically $1-2.5 \mu \mathrm{L}$, containing $\sim 10 \mathrm{ng} \mathrm{A} \beta / \mu \mathrm{L}$ ), little or no immunohistochemically detectable $\mathrm{A} \beta$ remained after a few days or more of incubation. However, by 3 to 5 mo postsurgery, at a point when the transgenic mice had not yet begun to form endogenous $\mathrm{A} \beta$ plaques and CAA, $\mathrm{A} \beta$ deposits emerged and increased dramatically with longer incubation intervals (Fig. 3).

The degree of $A \beta$-seeding in mice is directly proportional to the concentration of the brain extract (Meyer-Luehmann et al. 2006; Fritschi et al. 2014b). Seeded A $\beta$ deposits are both diffuse and congophilic, and dense-core (congophilic) plaques are associated with cellular reactivity that includes microgliosis, astrocytosis, and abnormal neurites containing increased APP and hyperphosphorylated tau. Importantly, no $A \beta$ deposits emerged in nontransgenic host mice, and brain extracts from non-AD control donors that lacked $\mathrm{A} \beta$ deposition did not induce signif-

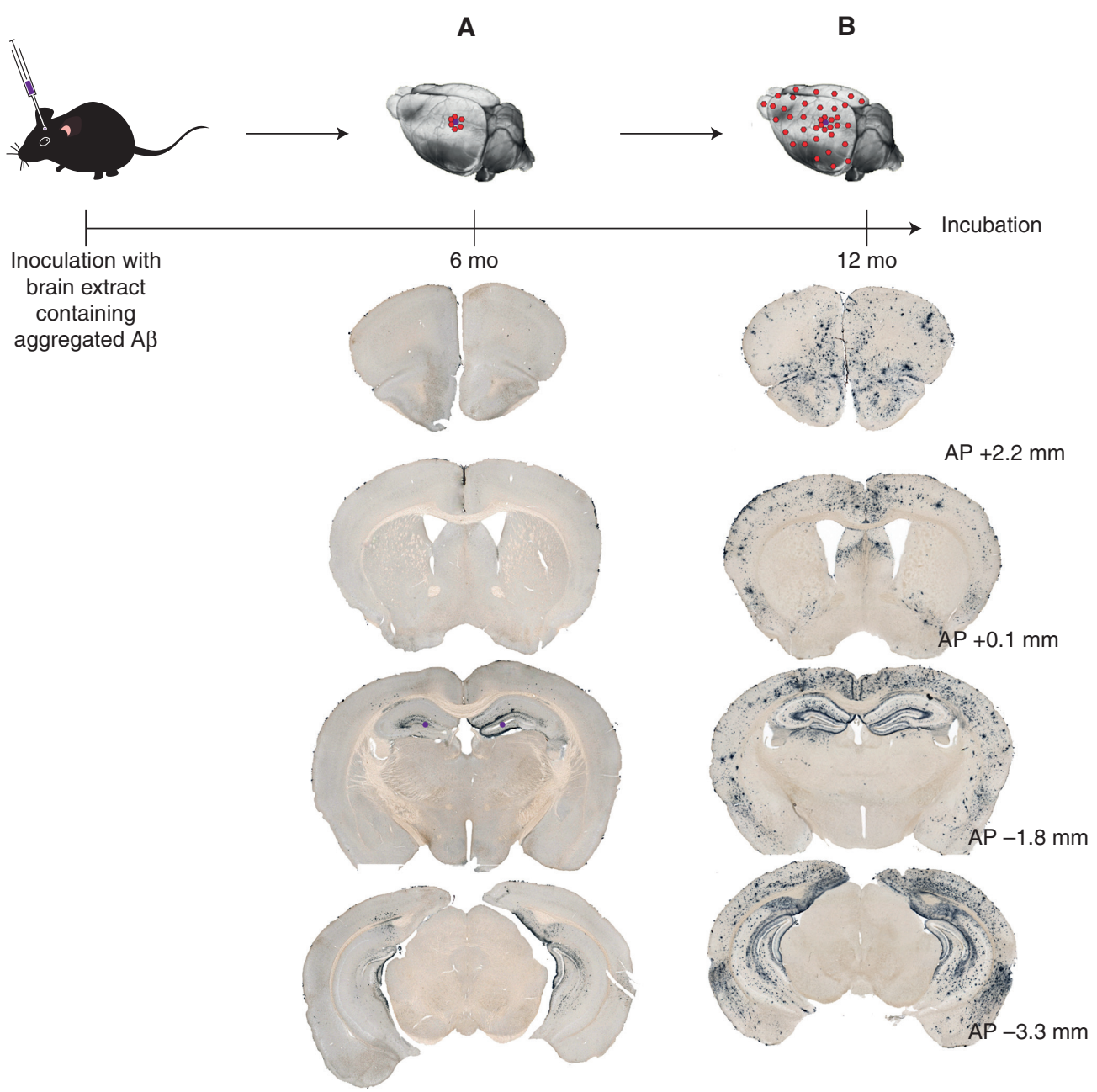

Figure 3. Induction and spread of amyloid- $\beta$ (A $\beta$ ) lesions in an A $\beta$-precursor protein (APP)-transgenic mouse model. A $\beta$ seed-laden brain extract was bilaterally injected into the hippocampus and overlying neocortex of R1.40 APP-transgenic mice. The injection site is marked in purple. (A) After a 6-mo incubation period, A $\beta$ deposition appeared mainly in the hippocampus. (B) After a 12-mo incubation period, spreading of $A \beta$ deposition to neighboring brain regions and throughout much of the forebrain was observed. (From Fritschi et al. 2013; modified with the authors' permission.) 
Prion-Like Properties of Aggregated A $\beta$

icant $\mathrm{A} \beta$ lesions (Kane et al. 2000; Meyer-Luehmann et al. 2006). NFTs per se have not been detected in seeded APP-transgenic mouse models and would likely require the expression of human-sequence tau in host mice (Bolmont et al. 2007).

These findings indicate that $A \beta$ seeding requires both a donor brain extract that contains $\mathrm{A} \beta$ seeds and a host that is capable of generating $\mathrm{A} \beta$ plaques and/or $\mathrm{CAA}$ of the $\mathrm{A} \beta$ type. Because injections of control brain extracts failed to seed plaque formation, these findings also mitigate against the possibility that the induction of $A \beta$ deposition is simply caused by brain injury. The concern that the seeding effect might result from factors in the human brain that indirectly stimulate $A \beta$ aggregation, such as a human-specific virus or an immune response to the foreign brain fractions, was ruled out by a robust seeding response to $A \beta$-rich brain extracts from aged APP transgenic donor mice of the same strain as the host mice (MeyerLuehmann et al. 2006; Watts et al. 2011).

The next step was to define the nature of the A $\beta$ seeds. Denaturation of brain extracts with formic acid (Meyer-Luehmann et al. 2006), or the specific depletion of $A \beta$ by antibodies or reagents that bind and remove amyloid proteins from the extract, abrogated the seeding effect (Meyer-Luehmann et al. 2006; Duran-Aniotz et al. 2014). Seeding was also blocked when the extract was mixed with an $\mathrm{A} \beta$ antibody and then injected into the brain (Meyer-Luehmann et al. 2006).

These results confirmed that $A \beta$ is essential to the seeding capacity of brain extracts, but they left open the question of whether pure, aggregated, synthetic $A \beta$ is able to induce deposition in mice. In early experiments, the injection of various amounts of synthetic $A \beta$ fibrils did not cause obvious induction of new plaques up to 5 mo postinjection (Meyer-Luehmann et al. 2006). This finding was not entirely unexpected, given the poor potency of recombinant $\mathrm{PrP}$ in inducing brain disease (Legname et al. 2004). More recently, however, it was shown that with a larger dose of aggregated $A \beta$ and a longer incubation time, $A \beta$ deposition can be instigated by multimeric, synthetic A $\beta$ (Stöhr et al. 2012).
$\mathrm{A} \beta$ seeds, then, like PrP prions, gain considerable potency when formed within the brain. The seeded conversion of synthetic $A \beta$ into potent, in vivo-active $A \beta$ seeds has recently been achieved in a hippocampal slice culture model (Novotny et al. 2016). Further deciphering of the factors responsible for the conversion will be important to understanding the pathogenicity of multimeric $A \beta$ in $A D$. For instance, the addition of certain cofactors to the medium in which synthetic PrP is aggregated augments the seeding potential of synthetic PrP prions (Wang et al. 2010; Deleault et al. 2012; Zhang et al. 2014). It will be informative to determine whether cofactors might also increase the potency of synthetic $A \beta$ seeds.

\section{THE INTERACTION OF A $\beta$ STRAINS AND HOST FACTORS}

To induce $A \beta$ deposition in the in vivo seeding model, it is necessary for the host animal to express seeding-capable A $\beta$ (Kane et al. 2000; Meyer-Luehmann et al. 2006; Morales et al. 2012; Rosen et al. 2012). In earlier studies, transgenic mouse models that eventually develop endogenous $A \beta$ lesions as they age were used. Prion disease, however, is induced de novo by infection with PrP prions in animals that otherwise would never have manifested the disease. To determine whether $A \beta$ deposits can also be generated de novo in relatively resistant animals, $\mathrm{A} \beta$-seeding experiments were undertaken in APP-transgenic mice (Morales et al. 2012) and rats (Rosen et al. 2012) that do not generate plaques or CAA within their normal life spans. In both instances, $A \beta$ deposition was induced in the brain after a suitable incubation period.

The existence of variant structural strains of $\mathrm{A} \beta$ is increasingly well established (Eisenberg and Jucker 2012; Lu et al. 2013; Hatami et al. 2014; Spirig et al. 2014; Cohen et al. 2015). Growing evidence supports the hypothesis that $A \beta$ seeds, like PrP prions (Aguzzi et al. 2007; Collinge and Clarke 2007; Prusiner 2013), can also adopt different molecular conformations that are linked to their functionality in vivo (MeyerLuehmann et al. 2006; Eisenberg and Jucker 2012; Stöhr et al. 2014; Watts et al. 2014). 
APP-transgenic mice (APP23 mice) and transgenic mice expressing human APP along with human presenilin-1 (APPPS1 mice) develop parenchymal $A \beta$ deposits that differ morphologically at the light-microscopic level (Heilbronner et al. 2013). When $A \beta$-laden brain extract from one model was injected intracerebrally into the other model, the lesion morphologies, as revealed by immunohistochemistry, and the molecular architecture of the deposited $A \beta$, as assessed by amyloid conformation-sensitive oligothiophene dyes, showed characteristics of both the host and seeding extract (Heilbronner et al. 2013). Interestingly, the ratio of $A \beta 40$ to $A \beta 42$ in the induced $A \beta$ deposits in host mice also was influenced by exogenous seeds, suggesting that this ratio may contribute to the strain-like properties of $A \beta$ assemblies (Heilbronner et al.2013). Transmission studies have found that brain extracts from $A D$ patients carrying either the Swedish or Arctic mutation injected into the brains of susceptible mice induced distinct $A \beta$ pathologies that could be serially propagated and maintained after multiple passages (Watts et al.2014). Finally, in a given host model, if seeds are infused into brain regions other than the hippocampus, the deposits that emerge are often typical of the morphotypes displayed by the endogenous (unseeded) lesions that form in the respective structures as the mice age (Eisele et al. 2009). Hence, not only the host mouse but also the local brain conditions influence the types of lesions that are induced by exogenous $A \beta$ seeds.

\section{THE SIZE AND POTENCY OF A $\beta$ SEEDS}

Prions exist in a range of sizes, and the most potent PrP prions appear to be small, soluble species (Silveira et al. 2005). To assess the size range of $A \beta$ seeds, brain extracts were subjected to ultracentrifugation $(100,000 \times g$ for $1 \mathrm{~h})$. Most $(>99 \%)$ of the A $\beta$ from the extract sediments in the pellet, which, when injected intracerebrally into mice, seeds $A \beta$ aggregation almost as effectively as does the original brain extract. Surprisingly, however, soluble A $\beta$ in the high-speed supernatant seeded $\sim 30 \%$ as much histochemically detectable $\mathrm{A} \beta$ deposition as did the insoluble pellet, although $<1 \%$ of the
$A \beta$ was in the soluble fraction. Therefore, small, soluble $A \beta$ assemblies, like small PrP prions, are highly effective seeds. Given their limited dimensions, it is conceivable that soluble $A \beta$ seeds traffic through the brain more readily than do larger fibrils. Interestingly, these soluble seeds, unlike insoluble multimers, are quite sensitive to destruction by proteinase $\mathrm{K}(\mathrm{PK})$, suggesting that they may be particularly susceptible to therapeutic intervention (Langer et al. 2011).

To assess the potency of $A \beta$ seeds in stimulating cerebral $A \beta$-deposition, serially diluted brain extracts from autopsied $\mathrm{AD}$ patients were injected into the hippocampus of young, APP-transgenic host mice. The degree of induction diminished with increasing dilution, but even subattomolar levels of brain-derived $A \beta$ were found to stimulate $A \beta$-proteopathy in the hosts (Fritschi et al. 2014b). In a recent experiment, $A \beta$ seed-rich brain extracts were injected into APP-null host mice that, because of the absence of $A \beta$, are incapable of replicating $\mathrm{A} \beta$ seeds; 6 mo later, brain extracts from these APP-null mice were still able to seed A $\beta$ deposition in APP-transgenic hosts, indicative of extraordinary potency and robustness of $A \beta$ seeds (Ye et al. 2015a). Surprisingly, A $\beta$ in the cerebrospinal fluid (CSF) of AD patients and aged APP-transgenic donor mice was devoid of significant in vivo seeding activity, even at levels of $\mathrm{A} \beta$ exceeding those in the most concentrated brain extracts (Fritschi et al. 2014b). The reasons for the inability of $A \beta$ in the CSF to seed in vivo remain uncertain, but the mechanism could reveal a novel means of impeding the seeding cascade in the brain.

\section{THE ROBUSTNESS OF A $\beta$ SEEDS}

Although PrP prions vary in their stability (Tzaban et al. 2002; Choi et al. 2010; Zou et al. 2010; Gambetti et al. 2011), a notable characteristic of infectious prions is that some of them are quite durable, even under harsh environmental conditions (Appel et al. 2001; Wiggins 2009). The ability of these prions to retain their pathogenic properties contributes to their infectivity, including rare instances of infection in neurosurgical patients exposed to $\operatorname{PrP}$ 
Prion-Like Properties of Aggregated A $\beta$

prion-contaminated surgical instruments that had been sterilized via conventional methods (Brown et al. 2012; Thomas et al. 2013). Studies in experimental animals confirm the persistent infectivity of PrP prions bound to stainless-steel wire (Flechsig et al. 2001), even after the wire has been exposed to formaldehyde (Zobeley et al. 1999).

A first hint that $A \beta$ seeds are also durable agents came from studies in which $A \beta$-rich brain extract was boiled for $5 \mathrm{~min}$ and still retained its seeding capacity (Meyer-Luehmann et al. 2006). In later studies drawing from work in the PrP prion field, a minute quantity of $A \beta$ rich brain extract was dried onto stainless-steel wires, and the wires were implanted in the brains of APP-transgenic host mice (Eisele et al. 2009). After an incubation period of $4 \mathrm{mo}$, $\mathrm{A} \beta$ lesions were induced in the region immediately surrounding the wire and, to a lesser extent, in more distant areas. Plasma sterilization of the contaminated wires before implantation prevented plaque induction, but heating them for $10 \mathrm{~min}$ at $95^{\circ} \mathrm{C}$ did not (Eisele et al. 2009). Although this study suggests that $A \beta$ seeds on insufficiently sterilized surgical instruments might increase the risk of $\mathrm{AD}$, presently this is only a theoretical possibility.

One of the first clues that the agent that transmits PrP prion disease is highly unorthodox surfaced unexpectedly in the 1930s when William Gordon immunized sheep against a viral illness called louping-ill (Gordon 1946). The vaccine was prepared from formaldehyde-fixed nervous tissue derived from sheep that had been sick with louping-ill. Although the vaccine worked well to reduce the incidence of louping-ill, after several years the vaccinated sheep began to develop scrapie. Gordon surmised that some of the sheep used to prepare the vaccine were also incubating the scrapie agent and that the agent is resistant to inactivation by formaldehyde (Gordon 1946). This conclusion has been supported by subsequent research (Pattison 1965; Brown et al. 1990).

To determine whether $A \beta$ seeds are similarly resistant to formaldehyde inactivation, formaldehyde-fixed brain samples from AD patients and APP-transgenic mice were injected into
APP-transgenic hosts. The fixed brain samples retained their seeding potential, even after as long as $2 \mathrm{yr}$ in formaldehyde (Fritschi et al. 2014a). Additionally, the spectral patterns of luminescent conjugated oligothiophenes bound to $A \beta$ indicated that the molecular architecture of the $A \beta$ seeds was maintained in fixed tissue and could be faithfully transmitted to the host mice (Fritschi et al. 2014a).

\section{TRAFFICKING OF A $\beta$ SEEDS}

\section{Trafficking within the Brain}

PrP prion-laden extracts injected into the brains of transgenic mice yield pathology that is not restricted to the injection site; rather, the PrP prions propagate and spread throughout most of the brain (Fraser 1982; Buyukmihci et al. 1983; Kimberlin and Walker 1986; Liberski et al. 2012; Rangel et al. 2014). In the case of AD, the neuroanatomical distribution of plaques and tangles at different disease stages suggests that the lesions propagate among axonally connected brain areas (Saper et al. 1987; Arnold et al. 1991; Braak and Braak 1995), a possibility that is garnering support from contemporary imaging modalities (Bero et al. 2011; Zhou et al. 2012; Iturria-Medina et al. 2014; Raj et al. 2015). Experimentally, within $24 \mathrm{~h}$ of injecting $\mathrm{A} \beta$-rich brain extract into the hippocampus, immunohistochemical examination shows that the extract diffuses away from the injection site and tends to concentrate along the hippocampal fissure, around blood vessels, and in the subpial zone, regions that exhibit a strong seeding response following a much longer incubation period (Walker et al. 2002; Ye et al. 2015b). The injected $A \beta$ rapidly becomes undetectable histochemically, and a lag period ensues before the focal emergence of induced deposits in the injected hippocampus, usually after a month or more depending on the mouse model (Kane et al. 2000; Meyer-Luehmann et al. 2006; Eisele et al. 2014). Over time, $A \beta$ deposits then begin to appear in other brain regions, most notably in the entorhinal cortex ventrolateral to the dorsal hippocampal injection site (Walker et al. 2002; Meyer-Luehmann et al. 2006; Eisele et al. 2009). 
L.C. Walker et al.

When the seeds are placed in the entorhinal cortex, the earliest secondary deposits emerge selectively in the hippocampal formation (Eisele et al. 2009). Because the entorhinal cortex is a major source of neocortical communication with the hippocampal formation (Suh et al. 2011; Arszovszki et al. 2014), these studies provided the first clues that neuronal pathways might define the spread of $A \beta$ pathology through the brain.

To further test the hypothesis that $A \beta$ seeds propagate by sequential seeding requires extending the incubation period into the age when most transgenic mouse models begin to generate deposits on their own. For this purpose, the R1.40 APP-transgenic mouse model (Lamb et al. 1997) was used. These mice do not start to form endogenous $A \beta$ plaques until 15 mo of age, providing a wide time window within which to observe the spread of lesions following focal seeding in the hippocampus. R1.40 mice were injected intracerebrally with $\mathrm{A} \beta$ seeds at 3 mo of age, and by 15 mo, much of the brain was beset by $A \beta$ deposits (Hamaguchi et al. 2012). Analysis of seeded R1.40 mice and APPPS1 mice at different time points supports the hypothesis that the infusion of exogenous seeds into the hippocampus elicits the spread of lesions along axonal routes; specifically, $A \beta$ deposits appear in structures of the limbic connectome and subsequently in regions that are increasingly distant from the initial site of injection (Fig. 3) (Ye et al. 2015b). A similar systematic emergence of endogenous $A \beta$ lesions has been reported in an APP-transgenic mouse model expressing Arctic mutant A $\beta$ (Rönnbäck et al. 2012).

These findings suggest that $A \beta$ aggregates traffic along neuronal pathways, but whether this occurs by constrained diffusion along fiber pathways or by active uptake and transport by neurons has not yet been determined in vivo. In addition, the role of the transgene promoter in defining the regional emergence of lesions remains to be fully defined. However, in vitro studies have shown that cultured neurons can take up and transport multimeric A $\beta$ (Nath et al. 2012; Domert et al. 2014; Song et al. 2014). In addition, it is important to consider the possibility that exogenous $A \beta$ seeds (and their endogenous descendants) can translocate by other means. In mice seeded intrahippocampally with $A \beta$-rich brain extracts, we have noted the premature appearance of CAA in the thalamus (Meyer-Luehmann et al. 2006). How thalamic CAA is stimulated in hippocampally seeded mice remains unknown. In this light, alternative modes of seed trafficking, beyond passive diffusion and neuronal transport, should be considered. These include perivascular and paravascular flow (Weller et al. 1998; Thal et al. 2007; Iliff et al. 2012) or uptake and transport by nonneuronal cells such as macrophages (Eisele et al. 2009) (see below).

\section{Trafficking from the Periphery to the Brain}

The infectivity of PrP seeds commonly involves their translocation from the periphery to the brain (Aguzzi 2003). To study whether A $\beta$ seeds delivered to peripheral sites can stimulate the formation of $A \beta$ plaques or CAA in the brain, APP transgenic mice were inoculated via various routes. In a first report, the oral, intranasal, and intravenous delivery of $A \beta$ seeds failed to induce significant plaque formation in the brain, at least within the incubation period examined (Eisele et al. 2009). However, in subsequent studies using a slightly prolonged incubation time, the injection of aggregated $A \beta$-rich brain extracts into the peritoneal cavity induced significant cerebral $\mathrm{A} \beta$-amyloidosis, particularly in the cerebral vasculature (Eisele et al. 2010, 2014). The magnitude of the seeding effect correlated with the amount of intraperitoneally inoculated $A \beta$ seeds and with the expression of $\mathrm{APP} / \mathrm{A} \beta$ in the brain (but not in the periphery). The pattern of immunoreactive lesions in this model suggests that the $A \beta$ seeds enter the brain at multiple sites (Eisele et al. 2014). Thus, $A \beta$ seeds, like PrP prions, can reach the brain from outside the central nervous system (CNS). How they do this remains uncertain; transport by macrophages through the bloodstream is one possibility (Eisele et al. 2014; Cintron et al. 2015), but alternative routes of conveyance (such as neuronal transport) could also be involved. 
Prion-Like Properties of Aggregated A $\beta$

\section{EVIDENCE FOR THE PRION-LIKE SEEDING OF A $\beta$ IN HUMANS}

From the late 1950s until 1985, a number of children with conditions such as short stature were treated with growth hormone that had been isolated from cadaveric human pituitary glands. Much later it was discovered that some batches of the hormone were contaminated with PrP prions, resulting in iatrogenic Creutzfeldt-Jakob disease (CJD) in a subset of patients (Rudge et al. 2015). Recently, eight hormone recipients in Great Britain who died of CJD at ages ranging from 36 to $51 \mathrm{yr}$ were examined for the co-presence of AD-type lesions. Four of them had significant $A \beta$ accumulation in the form of $\mathrm{A} \beta$ plaques and $\mathrm{CAA}$, and two others had sparse A $\beta$ deposits (Jaunmuktane et al. 2015). These findings raise the possibility that some batches of growth hormone were contaminated with $A \beta$ seeds that originated from pituitary glands collected from patients who had died with AD (or incipient AD) (Jucker and Walker 2015). Because the growth hormone recipients had died of CJD, it is unknown whether they ultimately would have developed AD (none of them displayed signs of tauopathy). It will be informative to follow the surviving recipients who did not manifest CJD to assess their relative risk of $\mathrm{AD}$ and other neurodegenerative proteopathies. A preliminary analysis in the United States suggests that growth hormone recipients may not be more likely to develop AD (Irwin et al. 2013), although a very long incubation period is likely. Also important will be to examine any remaining batches of cadaveric growth hormone for the presence of $A \beta$ and other types of prion-like seeds. Very recently, CJD patients who had received PrP prion-contaminated dura mater transplants many years earlier were also found to have significantly increased $\mathrm{A} \beta$ plaques and CAA (Frontzek et al. 2016).

These studies have furnished the first evidence that the aggregation of a protein other than PrP can be instigated in the human brain by exogenous seeds, but in neither case was full-blown $\mathrm{AD}$ induced, nor do the findings suggest that $\mathrm{AD}$ can be transmitted from person to person under ordinary circumstances. Rather, current evidence indicates that AD begins endogenously with the misfolding, corruptive templating, and self-assembly of $A \beta$ (Jucker and Walker 2013). As noted above, the risk of $\mathrm{AD}$ is increased by mutations and polymorphisms that promote $A \beta$ misfolding and aggregation. Whether and how physiological and environmental factors influence the $\mathrm{A} \beta$ cascade and how the aggregation of $A \beta$ is ultimately linked to dementia remain open questions, but it now seems likely that $\mathrm{A} \beta$ aggregation is a central mechanism on which risk factors converge to facilitate the development of $\mathrm{AD}$.

\section{CONCLUSIONS: THE PRION PARADIGM, $\mathrm{A} \beta$, AND AD}

Considerable research now supports the conclusion that $A \beta$ can be induced to aggregate and spread in the brain by a prion-like mechanism. $\mathrm{AD}$ involves a clinically silent period of intracerebral protein aggregation that precedes dementia by decades (Jack et al. 2010; Holtzman et al. 2011; Selkoe 2011; Bateman et al. 2012). In this light, the seeding model of $A \beta$ deposition substantiates a primary role for $A \beta$ aggregation in the early stages of $\mathrm{AD}$ and reinforces the logic of therapeutically targeting $A \beta$ seeds (Jucker and Walker 2011), preferably early in the pathogenic cascade.

In Table 1, we summarize the features of $A \beta$ seeds that justify their inclusion within the widening context of the prion concept. Fully developed $\mathrm{AD}$ has not yet been induced in any animal model; indeed, AD appears to be unique to humans (Walker and Cork 1999; Jucker 2010; Heuer et al. 2012). In addition, there is no definitive evidence to date that $\mathrm{AD}$ per se can be transmitted to humans by infection with exogenous $A \beta$ seeds. However, the exogenous seeding model provides compelling evidence for a molecular mechanism by which $A \beta$ seeds act to instigate and perpetuate AD pathology. Present knowledge favors a pathogenic model in which $\mathrm{AD}$ originates from the endogenous generation of $A \beta$ seeds. For these reasons, and because 
L.C. Walker et al.

Table 1. Comparison of PrP prions and $A \beta$ seeds

\begin{tabular}{|c|c|c|}
\hline Properties & $\begin{array}{c}\text { PrP } \\
\text { prions }\end{array}$ & $\begin{array}{c}\mathrm{A} \beta \\
\text { seeds }\end{array}$ \\
\hline \multicolumn{3}{|l|}{ Structure } \\
\hline$\beta$-sheet-enriched conformation & Yes & Yes \\
\hline Aggregation & Yes & Yes \\
\hline \multicolumn{3}{|l|}{ Seeding capacity } \\
\hline Seeds initiate pathology & Yes & Yes \\
\hline $\begin{array}{l}\text { Purified and synthetic materials } \\
\text { seed }\end{array}$ & Yes & Yes \\
\hline $\begin{array}{l}\text { Seeds instigate de novo } \\
\text { deposition }\end{array}$ & Yes & Yes \\
\hline \multicolumn{3}{|l|}{ Strain variation } \\
\hline Existence of different strains & Yes & Yes \\
\hline \multicolumn{3}{|l|}{ Stability } \\
\hline $\begin{array}{l}\text { Differential resistance to PK } \\
\text { digestion }\end{array}$ & Yes & Yes \\
\hline Resistance to high temperature & Yes & Yes \\
\hline $\begin{array}{l}\text { Resistance to formaldehyde } \\
\text { fixation }\end{array}$ & Yes & Yes \\
\hline \multicolumn{3}{|l|}{ Trafficking } \\
\hline $\begin{array}{l}\text { Spreading within and to the } \\
\text { brain }\end{array}$ & Yes & Yes \\
\hline \multicolumn{3}{|l|}{ Infectivity } \\
\hline Serial transmissibility in mice & Yes & Yes \\
\hline Transmissibility to humans & Yes & $(Y e s)^{\mathrm{a}}$ \\
\hline
\end{tabular}

the term "prion" is now widely used to refer to proteinaceous agents of biological information transfer in both health and disease, we suggest that the power of the prion concept can be enhanced by defining prions as "proteinaceous nucleating particles" (Walker and Jucker 2015). In light of this more comprehensive definition, research now supports the designation of $A \beta$ seeds as $A \beta$ prions. Defining prions according to their molecular properties has the additional advantage of mitigating unwarranted concern about the transmissibility of noninfectious proteopathies.

\section{ACKNOWLEDGMENTS}

We thank Sarah Fritschi and Ulrike Obermüller for their help in preparing this review and Simone Eberle for editorial assistance.

\section{REFERENCES}

Aguzzi A. 2003. Prions and the immune system: A journey through gut, spleen, and nerves. Adv Immunol 81: 123171.

Aguzzi A, Heikenwalder M, Polymenidou M. 2007. Insights into prion strains and neurotoxicity. Nat Rev Mol Cell Biol 8: $552-561$.

Alzheimer A. 1906. Über einen eigenartigen schweren Erkrankungsprozeß der Hirnrinde. Neurologisches Centralblatt 23: 1129-1136.

Appel T, Wolff M, von Rheinbaben F, Heinzel M, Riesner D. 2001. Heat stability of prion rods and recombinant prion protein in water, lipid and lipid-water mixtures. J Gen Virol 82: 465-473.

Arnold SE, Hyman BT, Flory J, Damasio AR, Van Hoesen GW. 1991. The topographical and neuroanatomical distribution of neurofibrillary tangles and neuritic plaques in the cerebral cortex of patients with Alzheimer's disease. Cereb Cortex 1: 103-116.

Arszovszki A, Borhegyi Z, Klausberger T. 2014. Three axonal projection routes of individual pyramidal cells in the ventral CA1 hippocampus. Front Neuroanat 8: 53.

Baker HF, Ridley RM, Duchen LW, Crow TJ, Bruton CJ. 1993. Evidence for the experimental transmission of cerebral $\beta$-amyloidosis to primates. Int J Exp Pathol 74: 441-454.

Bateman RJ, Xiong C, Benzinger TL, Fagan AM, Goate A, Fox NC, Marcus DS, Cairns NJ, Xie X, Blazey TM, et al. 2012. Clinical and biomarker changes in dominantly inherited Alzheimer's disease. N Engl J Med 367: 795-804.

Benilova I, Gallardo R, Ungureanu AA, Castillo Cano V, Snellinx A, Ramakers M, Bartic C, Rousseau F, Schymkowitz J, De Strooper B. 2014. The Alzheimer disease protective mutation A2T modulates kinetic and thermodynamic properties of amyloid- $\beta$ (A $\beta$ ) aggregation. $J$ Biol Chem 289: 30977-30989.

Bero AW, Yan P, Roh JH, Cirrito JR, Stewart FR, Raichle ME, Lee JM, Holtzman DM. 2011. Neuronal activity regulates the regional vulnerability to amyloid- $\beta$ deposition. Nat Neurosci 14: 750-756.

Biffi A, Greenberg SM. 2011. Cerebral amyloid angiopathy: A systematic review. J Clin Neurol 7: 1-9.

Bolmont T, Clavaguera F, Meyer-Luehmann M, Herzig MC, Radde R, Staufenbiel M, Lewis J, Hutton M, Tolnay M, Jucker M. 2007. Induction of tau pathology by intracerebral infusion of amyloid- $\beta$-containing brain extract and by amyloid- $\beta$ deposition in APP $\times$ tau transgenic mice. Am J Pathol 171: 2012-2020.

Braak H, Braak E. 1991. Neuropathological stageing of Alzheimer-related changes. Acta Neuropathol 82: 239-259.

Braak H, Braak E. 1995. Staging of Alzheimer's diseaserelated neurofibrillary changes. Neurobiol Aging 16: 271-278.

Brown P, Liberski PP, Wolff A, Gajdusek DC. 1990. Resistance of scrapie infectivity to steam autoclaving after formaldehyde fixation and limited survival after ashing at $360^{\circ} \mathrm{C}$ : Practical and theoretical implications. J Infect Dis 161: 467-472.

Brown P, Brandel JP, Sato T, Nakamura Y, MacKenzie J, Will RG, Ladogana A, Pocchiari M, Leschek EW, Schonberger 
Prion-Like Properties of Aggregated A $\beta$

LB. 2012. Iatrogenic Creutzfeldt-Jakob disease, final assessment. Emerg Infect Dis 18: 901-907.

Buyukmihci N, Goehring-Harmon F, Marsh RF. 1983. Neural pathogenesis of experimental scrapie after intraocular inoculation of hamsters. Exp Neurol 81: 396-406.

Choi YP, Peden AH, Gröner A, Ironside JW, Head MW. 2010. Distinct stability states of disease-associated human prion protein identified by conformation-dependent immunoassay. J Virol 84: 12030-12038.

Cintron AF, Dalal NV, Dooyema J, Betarbet R, Walker LC. 2015. Transport of cargo from periphery to brain by circulating monocytes. Brain Res 1622: 328-338.

Cohen ML, Kim C, Haldiman T, ElHag M, Mehndiratta P, Pichet T, Lissemore F, Shea M, Cohen Y, Chen W, et al 2015. Rapidly progressive Alzheimer's disease features distinct structures of amyloid- $\beta$. Brain 138: 1009-1022.

Collinge J, Clarke AR. 2007. A general model of prion strains and their pathogenicity. Science 318: 930-936.

Dartigues JF. 2009. Alzheimer's disease: A global challenge for the 21st century. Lancet Neurol 8: 1082-1083.

Deleault NR, Walsh DJ, Piro JR, Wang F, Wang X, Ma J, Rees JR, Supattapone S. 2012. Cofactor molecules maintain infectious conformation and restrict strain properties in purified prions. Proc Natl Acad Sci 109: E1938-E1946.

Di Fede G, Catania M, Morbin M, Rossi G, Suardi S, Mazzoleni G, Merlin M, Giovagnoli AR, Prioni S, Erbetta A, et al. 2009. A recessive mutation in the APP gene with dominant-negative effect on amyloidogenesis. Science 323: 1473-1477.

Domert J, Rao SB, Agholme L, Brorsson AC, Marcusson J, Hallbeck M, Nath S. 2014. Spreading of amyloid- $\beta$ peptides via neuritic cell-to-cell transfer is dependent on insufficient cellular clearance. Neurobiol Dis 65: 82-92.

Duran-Aniotz C, Morales R, Moreno-Gonzalez I, Hu PP, Fedynyshyn J, Soto C. 2014. Aggregate-depleted brain fails to induce $A \beta$ deposition in a mouse model of Alzheimer's disease. PloS ONE 9: e89014.

Duyckaerts C, Delatour B, Potier MC. 2009. Classification and basic pathology of Alzheimer disease. Acta Neuropathol 118: 5-36.

Eisele YS, Bolmont T, Heikenwalder M, Langer F, Jacobson LH, Yan ZX, Roth K, Aguzzi A, Staufenbiel M, Walker LC, et al. 2009. Induction of cerebral $\beta$-amyloidosis: Intracerebral versus systemic A $\beta$ inoculation. Proc Natl Acad Sci 106: $12926-12931$.

Eisele YS, Obermüller U, Heilbronner G, Baumann F, Kaeser SA, Wolburg H, Walker LC, Staufenbiel M, Heikenwalder M, Jucker M. 2010. Peripherally applied $A \beta$-containing inoculates induce cerebral $\beta$-amyloidosis. Science 330: 980-982.

Eisele YS, Fritschi SK, Hamaguchi T, Obermüller U, Füger P, Skodras A, Schäfer C, Odenthal J, Heikenwalder M, Staufenbiel M, et al. 2014. Multiple factors contribute to the peripheral induction of cerebral $\beta$-amyloidosis. J Neurosci 34: $10264-10273$.

Eisenberg D, Jucker M. 2012. The amyloid state of proteins in human diseases. Cell 148: 1188-1203.

Flechsig E, Hegyi I, Enari M, Schwarz P, Collinge J, Weissmann C. 2001. Transmission of scrapie by steel-surfacebound prions. Mol Med 7: 679-684.
Fraser H. 1982. Neuronal spread of scrapie agent and targeting of lesions within the retino-tectal pathway. Nature 295: $149-150$

Fritschi SK, Eftekharzadeh B, Manfredi G, Hamaguchi T, Heilbronner G, Nagarathinam A, Langer F, Eisele YS, Walker LC, Jucker M. 2013. The prion-like aspect of Alzheimer pathology. In Proteopathic seeds and neurodegenerative diseases (ed. Jucker M, Christen Y), pp. 61-69. Springer, Berlin.

Fritschi SK, Cintron A, Ye L, Mahler J, Bühler A, Baumann F, Neumann M, Nilsson KP, Hammarström P, Walker LC, et al. 2014a. A $\beta$ seeds resist inactivation by formaldehyde. Acta Neuropathol 128: 477-484.

Fritschi SK, Langer F, Kaeser SA, Maia LF, Portelius E, Pinotsi D, Kaminski CF, Winkler DT, Maetzler W, Keyvan $\mathrm{K}$, et al. 2014b. Highly potent soluble amyloid- $\beta$ seeds in human Alzheimer brain but not cerebrospinal fluid. Brain 137: 2909-2915.

Frontzek K, Lutz MI, Aguzzi A, Kovacs GG, Budka H. 2016. Amyloid- $\beta$ pathology and cerebral amyloid angiopathy are frequent in iatrogenic Creutzfeldt-Jakob disease after dural grafting. Swiss Med Wkly 146: w14287.

Gajdusek DC. 1994. Spontaneous generation of infectious nucleating amyloids in the transmissible and nontransmissible cerebral amyloidoses. Mol Neurobiol 8: 1-13.

Gambetti P, Puoti G, Zou WQ. 2011. Variably protease-sensitive prionopathy: A novel disease of the prion protein. J Mol Neurosci 45: 422-424.

Games D, Adams D, Alessandrini R, Barbour R, Berthelette P, Blackwell C, Carr T, Clemens J, Donaldson T, Gillespie F, et al. 1995. Alzheimer-type neuropathology in transgenic mice overexpressing V717F $\beta$-amyloid precursor protein. Nature 373: 523-527.

Giannakopoulos P, Herrmann FR, Bussière T, Bouras C, Kövari E, Perl DP, Morrison JH, Gold G, Hof PR. 2003. Tangle and neuron numbers, but not amyloid load, predict cognitive status in Alzheimer's disease. Neurology 60: $1495-1500$

Gordon WS. 1946. Advances in veterinary research. Vet Rec 58: $516-525$.

Götz J, Chen F, van Dorpe J, Nitsch RM. 2001. Formation of neurofibrillary tangles in P3011 tau transgenic mice induced by A 342 fibrils. Science 293: 1491-1495.

Haass C, Selkoe DJ. 2007. Soluble protein oligomers in neurodegeneration: Lessons from the Alzheimer's amyloid ß-peptide. Nat Rev Mol Cell Biol 8: 101-112.

Hamaguchi T, Eisele YS, Varvel NH, Lamb BT, Walker LC, Jucker M. 2012. The presence of $A \beta$ seeds, and not age per se, is critical to the initiation of $A \beta$ deposition in the brain. Acta Neuropathol 123: 31-37.

Hardy J, Selkoe DJ. 2002. The amyloid hypothesis of Alzheimer's disease: Progress and problems on the road to therapeutics. Science 297: 353-356.

Hatami A, Albay R III, Monjazeb S, Milton S, Glabe C. 2014. Monoclonal antibodies against $\mathrm{A} \beta 42$ fibrils distinguish multiple aggregation state polymorphisms in vitro and in Alzheimer disease brain. J Biol Chem 289: 32131-32143.

Heilbronner G, Eisele YS, Langer F, Kaeser SA, Novotny R, Nagarathinam A, Aslund A, Hammarström P, Nilsson KP, Jucker M. 2013. Seeded strain-like transmission of $\beta$-am- 
L.C. Walker et al.

yloid morphotypes in APP transgenic mice. EMBO Rep 14: 1017-1022.

Héraud C, Goufak D, Ando K, Leroy K, Suain V, Yilmaz Z, De Decker R, Authelet M, Laporte V, Octave JN, et al. 2014. Increased misfolding and truncation of tau in APP/PS1/tau transgenic mice compared to mutant tau mice. Neurobiol Dis 62: 100-112.

Heuer E, Rosen RF, Cintron A, Walker LC. 2012. Nonhuman primate models of Alzheimer-like cerebral proteopathy. Curr Pharm Des 18: 1159-1169.

Holtzman DM, Morris JC, Goate AM. 2011. Alzheimer's disease: The challenge of the second century. Sci Transl Med 3: 77sr71.

Hsiao K, Chapman P, Nilsen S, Eckman C, Harigaya Y, Younkin S, Yang F, Cole G. 1996. Correlative memory deficits, $\mathrm{A} \beta$ elevation, and amyloid plaques in transgenic mice. Science 274: 99-102.

Iliff JJ, Wang M, Liao Y, Plogg BA, Peng W, Gundersen GA, Benveniste H, Vates GE, Deane R, Goldman SA, et al. 2012. A paravascular pathway facilitates CSF flow through the brain parenchyma and the clearance of interstitial solutes, including amyloid $\beta$. Sci Transl Med 4: $147 \mathrm{ra} 111$.

Irwin DJ, Abrams JY, Schonberger LB, Leschek EW, Mills JL, Lee VM, Trojanowski JQ. 2013. Evaluation of potential infectivity of Alzheimer and Parkinson disease proteins in recipients of cadaver-derived human growth hormone. JAMA Neurol 70: 462-468.

Iturria-Medina Y, Sotero RC, Toussaint PJ, Evans AC, Alzheimer's Disease Neuroimaging Initiative. 2014. Epidemic spreading model to characterize misfolded proteins propagation in aging and associated neurodegenerative disorders. PLoS Comput Biol 10: e1003956.

Jack CR Jr, Knopman DS, Jagust WJ, Shaw LM, Aisen PS, Weiner MW, Petersen RC, Trojanowski JQ. 2010. Hypothetical model of dynamic biomarkers of the Alzheimer's pathological cascade. Lancet Neurol 9: 119-128.

Jaunmuktane Z, Mead S, Ellis M, Wadsworth JD, Nicoll AJ, Kenny J, Launchbury F, Linehan J, Richard-Loendt A, Walker AS, et al. 2015. Evidence for human transmission of amyloid- $\beta$ pathology and cerebral amyloid angiopathy. Nature 525: 247-250.

Jonsson T, Atwal JK, Steinberg S, Snaedal J, Jonsson PV, Bjornsson S, Stefansson H, Sulem P, Gudbjartsson D, Maloney J, et al. 2012. A mutation in APP protects against Alzheimer's disease and age-related cognitive decline. Nature 488: 96-99.

Jucker M. 2010. The benefits and limitations of animal models for translational research in neurodegenerative diseases. Nat Med 16: 1210-1214.

Jucker M, Walker LC. 2011. Pathogenic protein seeding in Alzheimer disease and other neurodegenerative disorders. Ann Neurol 70: 532-540.

Jucker M, Walker LC. 2013. Self-propagation of pathogenic protein aggregates in neurodegenerative diseases. Nature 501: 45-51.

Jucker M, Walker LC. 2015. Amyloid- $\beta$ pathology induced in humans. Nature 525: 193-194.

Kane MD, Lipinski WJ, Callahan MJ, Bian F, Durham RA, Schwarz RD, Roher AE, Walker LC. 2000. Evidence for seeding of $\beta$-amyloid by intracerebral infusion of Alz- heimer brain extracts in $\beta$-amyloid precursor proteintransgenic mice. J Neurosci 20: 3606-3611.

Kimberlin RH, Walker CA. 1986. Pathogenesis of scrapie (strain 263K) in hamsters infected intracerebrally, intraperitoneally or intraocularly. J Gen Virol 67: 255-263.

Klein WL. 2013. Synaptotoxic amyloid- $\beta$ oligomers: A molecular basis for the cause, diagnosis, and treatment of Alzheimer's disease? J Alzheimers Dis 33(Suppl 1): S49S65.

Knopman DS, Parisi JE, Boeve BF, Cha RH, Apaydin H, Salviati A, Edland SD, Rocca WA. 2003. Vascular dementia in a population-based autopsy study. Arch Neurol 60: $569-575$.

Lamb BT, Call LM, Slunt HH, Bardel KA, Lawler AM, Eckman CB, Younkin SG, Holtz G, Wagner SL, Price DL, et al. 1997. Altered metabolism of familial Alzheimer's disease-linked amyloid precursor protein variants in yeast artificial chromosome transgenic mice. Hum Mol Genet 6: 1535-1541.

Langer F, Eisele YS, Fritschi SK, Staufenbiel M, Walker LC, Jucker M. 2011. Soluble $A \beta$ seeds are potent inducers of cerebral $\beta$-amyloid deposition. J Neurosci 31: 14488 14495.

Legname G, Baskakov IV, Nguyen HO, Riesner D, Cohen FE, DeArmond SJ, Prusiner SB. 2004. Synthetic mammalian prions. Science 305: 673-676.

Lewis J, Dickson DW, Lin WL, Chisholm L, Corral A, Jones G, Yen SH, Sahara N, Skipper L, Yager D, et al. 2001. Enhanced neurofibrillary degeneration in transgenic mice expressing mutant tau and APP. Science 293: 1487-1491.

Liberski PP, Hainfellner JA, Sikorska B, Budka H. 2012. Prion protein $(\mathrm{PrP})$ deposits in the tectum of experimental Gerstmann-Sträussler-Scheinker disease following intraocular inoculation. Folia Neuropathol 50: 85-88.

Lu JX, Qiang W, Yau WM, Schwieters CD, Meredith SC, Tycko R. 2013. Molecular structure of $\beta$-amyloid fibrils in Alzheimer's disease brain tissue. Cell 154: 1257-1268.

Meyer-Luehmann M, Coomaraswamy J, Bolmont T, Kaeser S, Schaefer C, Kilger E, Neuenschwander A, Abramowski D, Frey P, Jaton AL, et al. 2006. Exogenous induction of cerebral $\beta$-amyloidogenesis is governed by agent and host. Science 313: 1781-1784.

Morales R, Duran-Aniotz C, Castilla J, Estrada LD, Soto C. 2012. De novo induction of amyloid- $\beta$ deposition in vivo. Mol Psychiatry 17: 1347-1353.

Nath S, Agholme L, Kurudenkandy FR, Granseth B, Marcusson J, Hallbeck M. 2012. Spreading of neurodegenerative pathology via neuron-to-neuron transmission of $\beta$ amyloid. J Neurosci 32: 8767-8777.

Nelson PT, Alafuzoff I, Bigio EH, Bouras C, Braak H, Cairns NJ, Castellani RJ, Crain BJ, Davies P, Del Tredici K, et al. 2012. Correlation of Alzheimer disease neuropathologic changes with cognitive status: A review of the literature. J Neuropathol Exp Neurol 71: 362-381.

Neuropathology Group. Medical Research Council Cognitive Function and Aging Study. 2001. Pathological correlates of late-onset dementia in a multicentre, community-based population in England and Wales. Neuropathology Group of the Medical Research Council Cognitive Function and Ageing Study (MRC CFAS). Lancet 357: 169-175. 
Prion-Like Properties of Aggregated A $\beta$

Novotny R, Langer F, Mahler J, Skodras A, Vlachos A, Wegenast-Braun BM, Kaeser SA, Neher JJ, Eisele YS, Pietrowski $\mathrm{MJ}$, et al. 2016. Conversion of synthetic $A \beta$ to in vivo active seeds and amyloid plaque formation in a hippocampal slice culture model. J Neurosci 36: 5084-5093.

Pattison IH. 1965. Resistance of the scrapie agent to formalin. J Comp Pathol 75: 159-164.

Prusiner SB. 1984. Some speculations about prions, amyloid, and Alzheimer's disease. N Engl J Med 310: 661663.

Prusiner SB. 2013. Biology and genetics of prions causing neurodegeneration. Annu Rev Genet 47: 601-623.

Raj A, LoCastro E, Kuceyeski A, Tosun D, Relkin N, Weiner $\mathrm{M}$; for the Alzheimer's Disease Neuroimaging Initiative (ADNI). 2015. Network diffusion model of progression predicts longitudinal patterns of atrophy and metabolism in Alzheimer's disease. Cell Rep 10: 359-369.

Rangel A, Race B, Phillips K, Striebel J, Kurtz N, Chesebro B. 2014. Distinct patterns of spread of prion infection in brains of mice expressing anchorless or anchored forms of prion protein. Acta Neuropathol Commun 2: 8 .

Reijmer YD, Fotiadis P, Martinez-Ramirez S, Salat DH, Schultz A, Shoamanesh A, Ayres AM, Vashkevich A, Rosas D, Schwab K, et al. 2015. Structural network alterations and neurological dysfunction in cerebral amyloid angiopathy. Brain 138: 179-188.

Reitz C, Brayne C, Mayeux R. 2011. Epidemiology of Alzheimer disease. Nat Rev Neurol 7: 137-152.

Rönnbäck A, Sagelius H, Bergstedt KD, Näslund J, Westermark GT, Winblad B, Graff C. 2012. Amyloid neuropathology in the single Arctic APP transgenic model affects interconnected brain regions. Neurobiol Aging 33: 831 e811-e839.

Rosen RF, Fritz JJ, Dooyema J, Cintron AF, Hamaguchi T, Lah JJ, LeVine H III, Jucker M, Walker LC. 2012. Exogenous seeding of cerebral $\beta$-amyloid deposition in $\beta$ APPtransgenic rats. J Neurochem 120: 660-666.

Rudge P, Jaunmuktane Z, Adlard P, Bjurstrom N, Caine D, Lowe J, Norsworthy P, Hummerich H, Druyeh R, Wadsworth JD, et al. 2015. Iatrogenic CJD due to pituitaryderived growth hormone with genetically determined incubation times of up to 40 years. Brain 138: 3386-3399.

Saper CB, Wainer BH, German DC. 1987. Axonal and transneuronal transport in the transmission of neurological disease: Potential role in system degenerations, including Alzheimer's disease. Neuroscience 23: 389-398.

Schneider JA, Arvanitakis Z, Bang W, Bennett DA. 2007. Mixed brain pathologies account for most dementia cases in community-dwelling older persons. Neurology 69: 2197-2204.

Selkoe DJ. 2011. Resolving controversies on the path to Alzheimer's therapeutics. Nat Med 17: 1060-1065.

Silveira JR, Raymond GJ, Hughson AG, Race RE, Sim VL, Hayes SF, Caughey B. 2005. The most infectious prion protein particles. Nature 437: 257-261.

Song HL, Shim S, Kim DH, Won SH, Joo S, Kim S, Jeon NL, Yoon SY. 2014. $\beta$-Amyloid is transmitted via neuronal connections along axonal membranes. Ann Neurol 75: 88-97.

Spirig T, Ovchinnikova O, Vagt T, Glockshuber R. 2014. Direct evidence for self-propagation of different amy- loid- $\beta$ fibril conformations. Neurodegener Dis 14: 151159.

Stancu IC, Ris L, Vasconcelos B, Marinangeli C, Goeminne L, Laporte V, Haylani LE, Couturier J, Schakman O, Gailly P, et al. 2014. Tauopathy contributes to synaptic and cognitive deficits in a murine model for Alzheimer's disease. FASEB J 28: 2620-2631.

Stöhr J, Watts JC, Mensinger ZL, Oehler A, Grillo SK, DeArmond SJ, Prusiner SB, Giles K. 2012. Purified and synthetic Alzheimer's amyloid $\beta(\mathrm{A} \beta)$ prions. Proc Natl Acad Sci 109: 11025-11030.

Stöhr J, Condello C, Watts JC, Bloch L, Oehler A, Nick M, DeArmond SJ, Giles K, DeGrado WF, Prusiner SB. 2014. Distinct synthetic $A \beta$ prion strains producing different amyloid deposits in bigenic mice. Proc Natl Acad Sci 111: 10329-10334.

Sturchler-Pierrat C, Abramowski D, Duke M, Wiederhold KH, Mistl C, Rothacher S, Ledermann B, Bürki K, Frey P, Paganetti PA, et al. 1997. Two amyloid precursor protein transgenic mouse models with Alzheimer disease-like pathology. Proc Natl Acad Sci 94: 13287-13292.

Suh J, Rivest AJ, Nakashiba T, Tominaga T, Tonegawa S. 2011. Entorhinal cortex layer III input to the hippocampus is crucial for temporal association memory. Science 334: $1415-1420$.

Thal DR, Rüb U, Orantes M, Braak H. 2002. Phases of A $\beta$ deposition in the human brain and its relevance for the development of AD. Neurology 58: 1791-1800.

Thal DR, Larionov S, Abramowski D, Wiederhold KH, Van Dooren T, Yamaguchi H, Haass C, Van Leuven F, Staufenbiel M, Capetillo-Zarate E. 2007. Occurrence and colocalization of amyloid $\beta$-protein and apolipoprotein $\mathrm{E}$ in perivascular drainage channels of wild-type and APPtransgenic mice. Neurobiol Aging 28: 1221-1230.

Thomas JG, Chenoweth CE, Sullivan SE. 2013. Iatrogenic Creutzfeldt-Jakob disease via surgical instruments. J Clin Neurosci 20: 1207-1212.

Tzaban S, Friedlander G, Schonberger O, Horonchik L, Yedidia Y, Shaked G, Gabizon R, Taraboulos A. 2002. Protease-sensitive scrapie prion protein in aggregates of heterogeneous sizes. Biochemistry 41: 12868-12875.

Vasconcelos B, Stancu IC, Buist A, Bird M, Wang P, Vanoosthuyse A, Van Kolen K, Verheyen A, Kienlen-Campard P, Octave JN, et al. 2016. Heterotypic seeding of tau fibrillization by pre-aggregated $A \beta$ provides potent seeds for prion-like seeding and propagation of tau-pathology in vivo. Acta Neuropathol 131: 549-569.

Walker LC, Cork LC. 1999. The neurobiology of aging in nonhuman primates. In Alzheimer disease (ed. Terry RD, Katzman R, Bick KL, Sisodia SS), pp. 233-243. Lippincott Williams \& Wilkins, Philadelphia.

Walker LC, Jucker M. 2015. Neurodegenerative diseases: Expanding the prion concept. Annu Rev Neurosci 38: 87103.

Walker LC, Callahan MJ, Bian F, Durham RA, Roher AE, Lipinski WJ. 2002. Exogenous induction of cerebral $\beta$-amyloidosis in $\beta$ APP-transgenic mice. Peptides 23: 1241-1247.

Wang F, Wang X, Yuan CG, Ma J. 2010. Generating a prion with bacterially expressed recombinant prion protein. Science 327: 1132-1135. 


\section{L.C. Walker et al.}

Watts JC, Giles K, Grillo SK, Lemus A, DeArmond SJ, Prusiner SB. 2011. Bioluminescence imaging of $A \beta$ deposition in bigenic mouse models of Alzheimer's disease. Proc Natl Acad Sci 108: 2528-2533.

Watts JC, Condello C, Stöhr J, Oehler A, Lee J, DeArmond SJ, Lannfelt L, Ingelsson M, Giles K, Prusiner SB. 2014 Serial propagation of distinct strains of $A \beta$ prions from Alzheimer's disease patients. Proc Natl Acad Sci 111: 10323-10328.

Weller RO, Massey A, Newman TA, Hutchings M, Kuo YM, Roher AE. 1998. Cerebral amyloid angiopathy: Amyloid $\beta$ accumulates in putative interstitial fluid drainage pathways in Alzheimer's disease. Am J Pathol 153: 725-733.

Wiggins RC. 2009. Prion stability and infectivity in the environment. Neurochem Res 34: 158-168.

Yamada M. 2013. Brain hemorrhages in cerebral amyloid angiopathy. Semin Thromb Hemost 39: 955-962.

Ye L, Fritschi SK, Schelle J, Obermüller U, Degenhardt K, Kaeser SA, Eisele YS, Walker LC, Baumann F, Staufenbiel
M, et al. 2015a. Persistence of A $\beta$ seeds in APP null mouse brain. Nat Neurosci 18: 1559-1561.

Ye L, Hamaguchi T, Fritschi SK, Eisele YS, Obermüller U, Jucker M, Walker LC. 2015b. Progression of seed-induced A $\beta$ deposition within the limbic connectome. Brain Pathol 25: 743-752.

Zhang Y, Wang F, Wang X, Zhang Z, Xu Y, Yu G, Yuan C, Ma J. 2014. Comparison of 2 synthetically generated recombinant prions. Prion 8: 215-220.

Zhou J, Gennatas ED, Kramer JH, Miller BL, Seeley WW. 2012. Predicting regional neurodegeneration from the healthy brain functional connectome. Neuron 73: 1216-1227.

Zobeley E, Flechsig E, Cozzio A, Enari M, Weissmann C. 1999. Infectivity of scrapie prions bound to a stainless steel surface. Mol Med 5: 240-243.

Zou WQ, Puoti G, Xiao X, Yuan J, Qing L, Cali I, Shimoji M, Langeveld JP, Castellani R, Notari S, et al. 2010. Variably protease-sensitive prionopathy: A new sporadic disease of the prion protein. Ann Neurol 68: 162-172. 


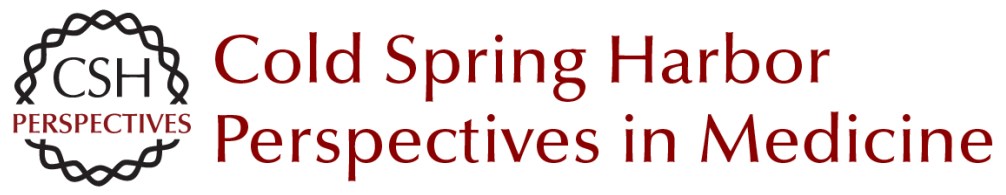

\section{The Prion-Like Properties of Amyloid- $\beta$ Assemblies: Implications for Alzheimer's Disease}

Lary C. Walker, Juliane Schelle and Mathias Jucker

Cold Spring Harb Perspect Med 2016; doi: 10.1101/cshperspect.a024398 originally published online June 7, 2016

\section{Subject Collection Prion Diseases}

TDP-43 Prions

Takashi Nonaka and Masato Hasegawa

$\alpha$-Synuclein: Multiple System Atrophy Prions

Amanda L. Woerman, Joel C. Watts, Atsushi

Aoyagi, et al.

Genetics of Synucleinopathies

Robert L. Nussbaum

$\beta$-Amyloid Prions and the Pathobiology of

Alzheimer's Disease Joel C. Watts and Stanley B. Prusiner

Disease Mechanisms of C9ORF72 Repeat

Expansions

Tania F. Gendron and Leonard Petrucelli

Chronic Traumatic Encephalopathy: Is Latency in Symptom Onset Explained by Tau Propagation? Joshua Kriegel, Zachary Papadopoulos and Ann C. McKee

Noncerebral Amyloidoses: Aspects on Seeding, Cross-Seeding, and Transmission Gunilla T. Westermark, Marcus Fändrich, Katarzyna Lundmark, et al.

Structural and Chemical Biology of Presenilin Complexes

Douglas S. Johnson, Yue-Ming Li, Martin Pettersson, et al.
Cell Biology and Pathophysiology of $\alpha$-Synuclein Jacqueline Burré, Manu Sharma and Thomas C. Südhof

Molecular Mechanisms of Chronic Wasting

Disease Prion Propagation Julie A. Moreno and Glenn C. Telling

Genetics of Amyotrophic Lateral Sclerosis Mehdi Ghasemi and Robert H. Brown, Jr.

The Genetics of C9orf72 Expansions Ilse Gijselinck, Marc Cruts and Christine Van Broeckhoven

Prion-Like Characteristics of

Polyglutamine-Containing Proteins Margaret M.P. Pearce and Ron R. Kopito

Therapeutic Strategies for Restoring Tau Homeostasis

Zapporah T. Young, Sue Ann Mok and Jason E. Gestwicki

Fused in Sarcoma Neuropathology in Neurodegenerative Disease Ian R.A. Mackenzie and Manuela Neumann

Experimental Models of Inherited PrP Prion Diseases Joel C. Watts and Stanley B. Prusiner

For additional articles in this collection, see http://perspectivesinmedicine.cshlp.org/cgi/collection/ 